variation) from many types of tree. There is a suggestion in this constancy that the tree produces some nitrogenous compound to an optimum concentration, either as an auxiliary to the synthesis of caoutchouc or as a side product of that synthesis.
Tristram's results thus throw an interesting light on such a suggestion, indicating the place of these reactions as in the Hevea leaves, a natural site for photosynthetic transformations. Further results in this field will be awaited with impatience.

\section{THE 200-IN.}

$\mathrm{T}$ HE twelfth Thomas Young Oration was delivered before a meeting of the Physical Society by Dr. H. Spencer Jones, Astronomer Royal, on May 30. He described some features of the 200-in. telescope now being constructed for the California Institute of Technology.

This telescope was made possible by a grant of six million dollars from the Rockefeller General Education Board. The design and construction of a telescope of double the aperture of the largest telescope previously built required careful considera. tion of a large number of problems. The primary problem was the construction of a 200 -in. mirror. If made, in accordance with previous practice, of a solid block of plate glass, annealing for nine years would have been required. Mirrors of stainless steel or of metal coated with glass of the same coefficient of expansion were considered but were regarded as too experimental ; fused quartz with a surface coating of clear quartz was tried but abandoned, not because the difficulties were insuperable but because the cost would have been too great. A special pyrex glass of high silica content, with a coefficient of expansion only three times that of quartz, was finally decided upon. The disk was cast, by a special technique evolved after much experimental work by the Corning Glass Company, with a ribbed honeycomb structure at the back to reduce the weight without sacrifice of rigidity. Annealing for ten months proved to be adequate for this special glass. The disk weighs $14 \frac{1}{2}$ tons and its optical figuring is well advanced.

The mounting embodies many new features. It is of a modified yoke type, the upper bearing being in the form of a giant horseshoe, $46 \mathrm{ft}$. in diameter, within the throat of which the telescope can lie for observations at the north pole of the sky. Only one machine in the world was large enough to machine this bearing. The yoke arms are hollow cylinders,

\section{TELESCOPE}

$10 \mathrm{ft}$. in diameter, joined by a bent box girder $46 \mathrm{ft}$ long, which carries the hemispherical thrust bearing, $7 \mathrm{ft}$. in diameter. An oil pad flotation system enables the $\$ 50$ tons of the moving parts to be turned with a torque of only $50 \mathrm{lb} . \mathrm{ft}$. The primary focus is at $f / 3 \cdot 3$ and the observer makes his observations within a 6-ft. diameter cylinder, supported from the upper cage of the tube. The Cassegrain focus is at $f / 16$ and observations can be made either at a focus just below the central hole of the 200 -in. mirror, where there is a platform for the observer, or, by the interposition of a diagonal flat mirror, within either of the hollow yoke arms. The Coude focus is at $f / 30$, and observations with high dispersion spectrographs can be made within a constant-temperature room just south of the telescope. At the primary focus, coma would be serious at a small angular distance from the axis; two special correcting lenses of zero power have been designed to eliminate coma. For observations of faint objects, with low-dispersion spectrographs, two special short-focus camera objectives of great relative aperture have been constructed; one of these, with relative aperture of $f / 0.35$, on the principle of the oil-immersion microscope objective, is of British design and construction. The ingenious image-slicer, designed by Dr. Bowen, will give a greatly increased efficiency in all spectrographic observations.

All auxiliary mirrors are permanently carried on the mounting and can be operated by remote control. The telescope drive is of an elaborate nature; the effects of changing refraction, of differential flexure and of errors in the gears are automatically allowed for by a system of 'computers'. A quartz-crystal oscillator provides the fundamental control of the rate of drive. A complicated system of Selsyn or interlock motors enables the telescope to be set rapidly to any predetermined position, the position of the dome and of the windscreen being automatically adjusted.

\title{
WIRED RADIO BROADCASTING
}

$\mathrm{W}$ IRED broadcasting has already appeared in service in Europe and other parts of the world. An article written by N. Shinohara and Y. Hirano, of the Ministry of Communications, Tokyo, in the January issue of the Nippon Electrical Communication Journal, a summary form in English of the journal of the Institute of Electrical Communication Engineers of Japan, discusses the subject, stress being laid on experiments and the basis of network design.

In one method, a wireless radio receiving and wired radio transmitting station is located at a position near a crowded area of listeners or in a suburban district, where there is little electrical disturbance. The programme received at this station is converted to audio-frequency and sent over special lines to the listeners. This method is known in Japan as an ordinary form of common broadcast reception. The pro. gramme is distributed at a fairly high level of volume, so that it is only necessary for the listener to instal a loudspeaker. The resulting low cost of the receiving apparatus is an advantage. The disadvantages, however, accompanying radio-broadcasting cannot be avoided, because this method has an intermediate wireless system. Also a large expenditure of money and materials is needed for the installation of special lines to listeners.

A second method makes use of telephone lines, to which the broadcast programme is supplied at audio-frequency. While this method greatly 
increases the efficiency of utilization of the telephone lines, the programme is subject to interruption by telephone calls, and it is found that a high level of broadcasting power, such as is used in the first method, cannot be transmitted directly through the lines.

A third method makes use of telephone lines, or lighting and power distribution lines, on which the programme is superimposed by means of a highfrequency carrier wave. In Japan this method has been adopted as the basic principle on which a wired broadcasting network may be established. While the percentage of telephone installations in Japan is low, the percentage of electric lighting is very high, being about 90 per cent, which is second to Switzerland's 99 per cent. The use of lighting and power lines together with telephone lines, therefore, would make it possible to develop an almost complete country-wide network.

Experiments on wired broadcasting in Japan have been going on since 1926 in the form of a carrier system over power and lighting lines. In 1935 , broadcasting on high-frequency carriers was proposed by the Ministry of Communications. It is interesting to note that when wired broadcasting on high frequencies was introduced, the aims stressed were the relieving of the congestion in allotted wave bands due to the development of broadcasting, and the distribution of clear, stable, high-quality programmes. In the present crisis, the mission of wire broadcasting has been extended to the important tasks of protecting broadcasts from outside interception and preventing false broadcasts.

In surveying the possibilities in Japan of telephone lines as circuits for wired broadcasting it is found that the number of telephones per 100 persons is 3.80 in cities having populations of 50,000 or more, and 0.84 in towns of smaller population; hence the reception of broadcasts over telephone subscribers' lines is effective only in cities having a high percentage of subscribers. The use of telephone lines is especially necessary in cities where power cables are employed for supplying electricity. Thus telephone lines ought to be utilized as much as possible in the busiest sections of a city and in districts where power cables are used, whereas overhead power and lighting lines ought to be used in the suburbs, in towns and villages, and in cities having overhead power distribution lines. It was considered best to standardize the carrier frequency at 130 kilocycles. This value would be the frequency for the distribution of wired broadcasts to listeners all over the country.

\section{FORTHCOMING EVENTS}

[Meetings marked with an asterisk are open to the public.]

\section{Tuesday, June I7}

Institute of Physics (London and Home Counties' Branch) (in the Lecture Hall of Messrs. Kodak, Ltd., Harrow), at 6 p.m.-Dr. D. A. Spencer : "The Applications of Photography in Engineering".

\section{Wednesday, June 18}

Birkbeck College (Bream's Buildings, Chancery Lane, London, E.C.4), at 6 p.m.-Foundation Oration by His Grace the Lord Archbishop of York: "Education and Peace".
Thursday, June Ig

Chadwick Public Lecture (at the Chelsea Physic Garden, Swan Walk, London, S.W.3), at 4 p.m.-Dr. J. Ramsbottom: "The Inter-relation of Man and Fungus in Health and Disease".*

Assocratron of Scientific Workers (Birmingham Branch) (at the University, Birmingham), at 7 p.m.Prof. J. D. Bernal, F.R.S.: "Science and Society".*

\section{APPOINTMENTS VACANT}

APPJiCATIONS are invited for the following appointments on or before the dates mentioned:

Head OF THE Electrical Section of the Engineering Department of the Oldham Municipal Technical College-The Director of Educa. tion, Education Offices, Oldham (June 20).

BORIUGH Electrical ENGINEER-The Town Clerk, Town Hall, Woolwich, London, S.E.18 (June 21).

LECTURER IN GeneraL SCIENCE including BIOLOGY and GardeNiNe

-The Principal, St. John's Training College, York (June 23).

DEPUTY BoROUGH ENAINEER AND SURVEYOR-The Borough Engineer and Surveyor, Town Hall, Barking, Essex (June 24).

Principal of the CaMbridgeshire Technical School-The Education Secretary, Cambridgeshire Education Committee, Shire Hall, Cambridge (June 24).

LeOTURER IN THE MEChaNical AND Civil ENgINeERINg DEPaRTMENT-The Secretary, Technical College, Sunderland (June 28).

ASSIBTANT TO THE ENGINEER-IN-CHIEF-The General Manager and Secretary, Mersey Docks and Harbour Board, Dock Office. Liverpoo (June 30).

\section{REPORTS AND OTHER PUBLICATIONS \\ (not included in the monthly Books Supplement)}

\section{Great Britain and Ireland}

Memoirs of the Cotton Research Station, Trinidad. Series $\mathbf{B}$ Physiology, No. 14: Concerning the Upward Movement of Soil Solutes, by T. G. Mason and F. Phillis; Studies on the Partition of Mineral Elements in the Cotton Plant, 2: Preliminary Observation on Potassium, Calcium and Magnesium, by E. Phillis and T. G. Mason On the Expression of Sap by Low Pressure, by E. Phillis and T. G. Mason. Pp. 36. (London: Empire Cotton Growing Corporation.)
$2 s$. 6d.

\section{Other Countries}

United States Department of the Interior: Geological Survey. Bulletin 899-B : Geologic Structure and Occurrence of Gas in part of Southwestern New York. Part 2 . Subsurface Structure in part of Southwestern New York and Mode Group By $\mathrm{B}$. Richardson Pp iii Group. By G. B. Richardson. Pp. iii $+69-93+$ plates $5-8$. 30 cents. Bulletin 922-J : Chromite Deposits in the Seiad Quadrangle, Siskiyou County, California. By G. A. Kynearson and C. T. Smith. (Strategí Minerais Investigations, 1940.) Pp. iv +281-306+plates 40-44. 30 cents. Bulletin 922-0 : Chromite Deposits of the Pilliken A rea, Eldo rado County, California. By F. G. Wells, L. R. Page and H. L. James. (Strategic Minerals Investigations, 1940.) Pp. iv +417-460+plates 66-69. 35 cents. Bulletin 922-P : Chromite Deposits in the Sourdough Area, Curry County, Oregon. By F. G. Wells, L. R. Page and H. L. James. (Strategic Minerals Investigations, 1940.) Pp. iv +461$494+$ plates $70-71$. 30 cents. (Washington, D.C. : Government Print-
ing Office.)

United States Departinent of the Interior: Geological Survey Professional Paper 196-A : Geology and Biology of North Atlantic Deep-Sea Cores between Newfoundland and Ireland. Summary of the Report ; Foreword, by C. S. Piggott ; General Introduction, by W. H. Bradley; Part 1: Lithology and Geologic Interpretations, by $\mathbf{M}$. N. Bramlette and W. H. Bradley; Part 2: Foraminifera, by Joseph A. Cushman and Lloyd G. Henbest. Pp. xv $+56+10$ plates. (Washington, D.C. : Government Printing Office.) 30 cents. [205 United States Department of Agriculture. Circular No. 594: The Use of Traps against the Japanese Beetle. By Walter E. Fleming, Use of Traps against the Japanese Beetle. By Walter E. Fleming,
Emory D. Burgess and Warren W. Maines. Pp. 12.5 cents. Miscellaneous Publication No. 417: Bark Beetles of the Genus Hylastes aneous Publication No. 417: Bark Beetles of the Genus Hylastes Erichson in North America. By M. W. Blackman. Pp. 28 . Technica Bulletin No. 757 : Parasites of the Birch Leaf-Mining Sawfly (Phyllo toma nemorata). By Philip B. Dowden. Pp. 56. 10 cents. (Washington,
D.C. : Government Printing Office.) Proceedings of the United States National Museum. Yol. 89, No. 3101: The Polyclad Flatworms of the Atlantic Coast of the United States and Canada. By Libbie H. Hyman. Pp. 449-496. Vol. 89, No. 3102: New Species of Heterocerous Moths in the United States National Museum. By William Schaus. Pp. 497-512. Vol. 89, No. 3105: Notes on Birds of the Guatemalan Highlands. By Alexander Wetmore. Pp. 523-582. (Washington, D.C.: Government Printing Office.)

Nyasaland Protectorate. Annual Report of the Forestry DepartGovernment Printer.) 1s. 31 st December 1940. Pp. 8. (Zomba: 